\title{
PENGARUH RELIGIUSITAS DAN TANGGUNG JAWAB SOSIAL TERHADAP ETOS KERJA ISLAMI PADA KARYAWAN \\ LEMBAGA FILANTROPI
}

\author{
Rozikan', Muhammad Zakiy ${ }^{2}$ \\ ${ }^{1}$ Universitas Muhammadiyah Yogyakarta, Email : rozikan.fai@umy.ac.id \\ ${ }^{2}$ Universitas Muhammadiyah Yogyakarta, Email : Muhammad.zakiy.fai@umy.ac.id
}

\begin{abstract}
ABSTRAK
Penelitian ini bertujuan untuk menganalisis pengaruh religiusitas dan tanggungjawab sosial terhadap etos kerja islami karyawan Lembaga Amil Zakat Muhammadiyah (LAZISMU). Penelitian dengan metode kuantitatif ini dilakukan Lazismu berjumlah 50 responden penelitian. Level analisis yang diguanakan yaitu individu dengan pengambilan data secara cross sectional dianalisis menggunakan regresi linier berganda. Hasil penelitian ini menunjukkan bahwa tanggungjawab sosial dapat meningkatkan etos kerja islami karyawan di Lembaga Amil Zakat Muhammadiyah dengan koefisien regresi sebesar $(\beta=0.355$; p-value $=0.000)$, sedangkan karakteristik religiusitas tidak berpengaruh terhadap etos kerja islami karyawan di Lembaga Amil Zakat nasional tersebut $(\beta=0.099$; $p$-value $=0.262)$. Hal ini membuktikan bahwasannya Lembaga Amil Zakat yang merupakan lembaga sosial, memerlukan karyawan yang memiliki tanggungjawab sosial yang tinggi. Adapun tidak berpengaruhnya karakteristik religiusitas dikarenakan karakteristik tersebut bukan prediktor utama dan tidak berkorelasi secara langsung dengan etos kerja islami. Kontribusi teoritis dan praktis dapat dilihat dalam penelitian ini, yaitu peran tanggungjawab sosial dalam meningkatkan etos kerja islami karyawan Lembaga Amil Zakat Muhammadiyah.
\end{abstract}

Kata Kunci: Religiusitas; Tanggungjawab Sosial; Etos Kerja; Filantropi.

\begin{abstract}
This study aims to analyze the effect of religiosity and social responsibility on the Islamic work ethic of the employees in the Amil Zakat Muhammadiyah Institution. Research with this quantitative method conducted in this institution amounted to 50 research respondents. We use of cross-sectional analysis using multiple linear regression. The results of this study indicate that social responsibility can improve employee work ethic at the Amil Zakat Institution, while the characteristics of religiosity do not affect the employee's work ethic at this national Amil Zakat Institution. This study proves that the Amil Zakat Institution, which is a social institution, requires employees who have high social responsibility. As for the influential characteristics of religiosity, the characteristics are not predictive and do not correlate directly with the Islamic work ethic. Theoretical and practical contributions in this study, are the role of social responsibility in improving the Islamic work ethic of the Amil Zakat Muhammadiyah Institution.
\end{abstract}

Keywords: Religiosity; Social Responsibility; Work Ethic; Philanthropy. 


\section{PENDAHULUAN}

Manusia dibekali dengan 2 (dua) kecenderungan yaitu kecendurungan fujur dan kecenderungan taqwa. Manusia akan dinilai dari pilihanya mengambil kecenderungan yang akan dominan pada dirinya. Kecenderungan itu akan muncul dan dapat dilihat dalam berbagai aktivitas yang dilakukan sehari-hari. Berbagai aktivitas yang dilakukan tersebut patut untuk selalu diperhatikan, mengingat dari kebiasaan-kebiasaan tersebut akan terbentuk karakter dan perilaku dari seseorang. Dari karakter dan perilaku tersebut kita dapat menilai baik buruknya, tinggi rendahnya etos kerja yang dilakukan orang tersebut. Begitu pula etos kerja dalam Islam yang selalu berusaha untuk berperilaku baik dan mengharapkan ridha Allah SWT yang kita sebut sebagai taqwa. Etos kerja dalam Islam merupakan usaha ilmuan dalam mengembangkan ilmu pengetahuan berbasis agama agar sejalan dengan konsep paradigma keilmuan (scientific paradigm). Namun harus diakui, hingga hari ini, nyatanya ada banyak nada pesimistis terhadap kemungkinan lahirnya sains baru berbasis agama (Muslih, 2018).

Agama Islam merupakan agama yang sangat menjunjung tinggi seseorang yang selalu mendekatkan diri dalam ketaqwaan. Ketaqwaan tidak selalu dikaitkan dengan ibadah mahdhoh saja. Akan tetapi, ketaqwaan juga dapat tercermin dari kualitas atas apa yang dikerjakan dalam beraktivitas. Al-Quran telah berbicara tentang apa yang harus dikerjakan oleh manusia dan menjelaskan tentang hasil yang akan didapat dari pekerjaan yang dilakukan. Hal tersebut seperti yang tertuang dalam Q.S. Al-An'am (6) ayat 135 yang berbunyi:

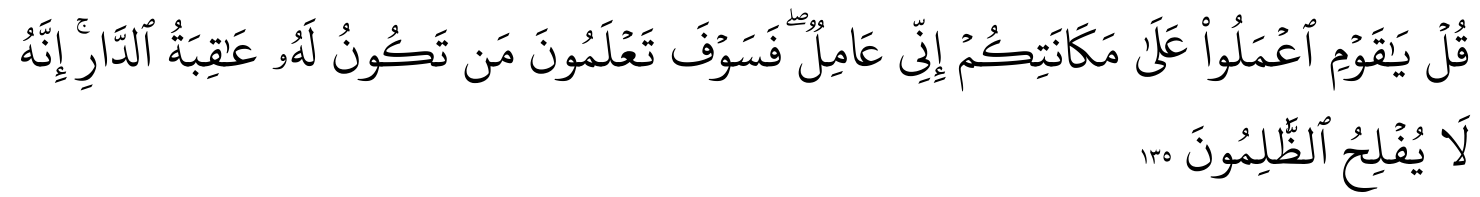

Artinya: Katakanlah: "Hai kaumku, berbuatlah sepenuh kemampuanmu, sesungguhnya akupun berbuat (pula). Kelak kamu akan mengetahui, siapakah (di antara kita) yang akan memperoleh hasil yang baik di dunia ini. Sesungguhnya orang-orang yang zalim itu tidak akan mendapatkan keberuntungan".

Manusia di dunia ini dituntut bekerja untuk memenuhi kebutuhanya dalam rangka beribadah kepada Allah SWT. Bekerja dalam Islam akan bernilai ibadah jika didasari dengan orientasi yang tidak semata-mata hanya pada materi saja. Berbagai jenis pekerjaan yang ada dapat tergolong pada jenis pekerjaan yang murni berorientasi pada bisnis semata ada pula yang didalamnya terdapat nilai sosial keagamaan. Seseorang yang bekerja pada perusahaan ataupun lembaga harus mempunyai semangat dan kinerja yang baik dalam melaksanakan amanah yang diberikan pada dirinya. Cara bekerja tersebut biasa disebut dengan etos kerja. Mengingat pentingnya etos kerja, 
Muhammadiyah selalu setia dan mendapat inspirasi dari tiga etos Alquran dalam mencapai tujuan membangun masyarakat Islam yang sesungguhnya, yaitu etos rahmat (welas asih), al-Ma'un dan al-'Ashr (Baidhawy, 2017). Untuk itu, sangat relevan jika Gerakan Muhammadiyah mendirikan sebuah Lembaga filantropi Islam yang berfokus pada kemaslahatan umat dan pemberdayaan kemiskinan.

Lembaga filantropi merupakan lembaga yang bergerak pada sosial keagamaan, maka lembaga filantropi membutuhkan karyawan yang memiliki karakter religiuisitas dan tanggungjawab sosial yang tinggi. Meskipun demikian, lembaga filantropi tidak kemudian mengesampingkan hak-hak para karyawan yang bernaung di dalamnya. Lembaga filantropi di Indonesia merupakan lembaga yang banyak mendapatkan kepercayaan masyarakat dalam menyalurkan zakat, infak, shadaqah maupun wakaf. Kepercayaan dari masyarakat terhadap Lembaga filantropi ini tidak terlepas dari peran media Islam yang sejak masa pergerakan terus menyebarkan ide-ide organisasi muslim termasuk filantropi (Hapsari, 2018). Namun, masih dibutuhkan literasi terkait Lembaga filantropi ini, mengingat kesadaran masyarakat untuk membayar zakat masih sangat rendah (Mubarok \& Fanani, 2014). Untuk mengatasi hal ini, dibutuhkan peran masjid sebagai media literasi untuk Lembaga filantropi, seperti yang telah dilakukan oleh Lembaga perbankan berupa Laku Pandai (Putri \& Firmansyah, 2017).

Strategi lain untuk meningkatkan kepercayaan nasabah adalah membangun kepercayaan dan loyalitas nasabah, sehingga literasi mengenai Lembaga filantropi dapat membekas dalam pikiran nasabah (Suwarsi \& Wulandari, 2017). Kepercayaan nasabah (Muzaki) dalam memberikan harta kepada lembaga filantropi merupakan amanah yang harus di tunaikan. Dari alasan tersebut, peneliti berharap sifat religiuisitas dan tanggungjawab sosial dapat meningkatkan etos kerja islami karyawan Lembaga filantropi dalam hal ini Lazismu. Sejalan dengan Baidhawy (2017) yang menjelaskan bahwa prospek Muhammadiyah sebagai gerakan dan organisasi sosial keagamaan makin cerah sejalan dengan kemampuan melakukan perubahan positif dalam perspektif pemberdayaan ummat.

Bagi seorang karyawan lembaga filantropi, etos kerja islami merupakan hal yang sangat penting, karena pekerjaan yang dilakukan merupakan pekerjaan yang mengandung unsur ibadah, pengabdian dan sekaligus tempat mencari rezeki untuk memenuhi kebutuhan sehari-hari. Ketertarikan peneliti meneliti tentang lembaga filantropi karena lembaga filantropi merupakan lembaga yang melayani umat dalam mengentaskan ketimpangan ekonomi, pendidikan dan pembangunan yang berkelanjutan dengan membiayai kegiatan-kegiatan yang produktif. Untuk itu, dibutuhkan sumber daya manusia yang memiliki semangat, motivasi, berpandangan kedepan dapat tercermin dari etos kerja Islami bagi pihak-pihak yang terlibat dalam 
lembaga filantropi tersebut. Dari uraian diatas, tujuan penelitian ini yaitu untuk melihat peran variabel religiuisitas dan tanggungjawab sosial dalam membentuk etos kerja Islami yang tinggi.

\section{TINJAUAN PUSTAKA}

\section{Etos Kerja Islami}

Kata etos juga dapat merujuk pada kata etika atau etiket yang memiliki arti semangat yang tinggi guna mengerjakan sesuatu dengan optimal dan menghindari kerusakan sehingga hasil yang diperoleh lebih baik. atau dalam Islam biasa disebut dengan ihsan (Tasmara, 2004).

Jika kata etos dikaitkan dengan kerja maka akan menciptakan makna yang khas. Etos kerja membentuk suatu sikap individual dan sosial masyarakat atau juga dapat berarti semangat kerja seseorang atau kelompok yang menjadi ciri khas. Atau dengan kata lain, etos kerja merupakan pandangan atau sikap seseorang akan kerja yang dilakukan dan dilatarbelakangi oleh keyakinan terhadap nilai-nilai yang dapat timbul dari agama tertentu. Etos kerja islami terpancar dari sistem keimanan/Aqidah islam berkenaan dengan kerja. Aqidah itu terbentuk oleh ajaran wahyu dan akal yang bekerjasama secara proporsional menurut Fungsi masing-masing.

Kata etos seringkali dikaitkan dengan kata "Kerja". Arti kerja bagi seorang muslim adlah suatu upaya sungguh sungguh, dengan mengerahkan seluruh aset, pikir dan dzikirnya untuk mengaktualisasikan atau menampakkan arti dirinya sebagai Hamba Allah. Yang harus menundukan dunia dan menempatkan dirinya sebagai bagian masyarakat yang terbaik (khoirul Ummah). Ada 2 Aspek yang harus dipenuhi secara nalar ketika aktivitas itu diakatan sebuah pekerjaan (Tasmara, 2004): Pertama kegiatan karena ada dorongan untuk mewujudkan sesuatu hingga timbul rasa tanggung jawab yang besar untuk menghasilkan karya atau produk yang berkualitas. Kedua apa yang dilakukan tersebut dilakukan karena kesengajaan, sesuatu yang direncanakan.

\section{Konsep Etos Kerja Islami}

Terdapat tiga tanggung jawab yang dihadapi seorang individu dalam bekerja, yaitu tanggung jawab kepada Allah, tanggung jawab kepada sendiri, dan tanggung jawab kepada orang lain. Kholis (2008) menjelaskan bahwa tanggung jawab kepada Allah dapat diuraikan sebagai berikut:

a. Iman sebagai landasan bekerja

Salah satu wujud keimanan adalah bekerja. Iman menjadi dasar keyakinan 
bahwa Allah menciptakan bumi berserta isinya untuk manusia. Di bumi dan isinya, Allah telah meletakkan rezeki bagi seseorang yang berusaha dengan gigih mendapatkannya. Sehingga apabila gagal dalam suatu hal hendaknya jangan berputus asa karena Allah masih memberikan rezeki lainnya. Di lain sisi, ketika datang suatu keberhasilan maka jangan mudah sombong karena keberhasilan itu tidak datang hanya karena usaha sendiri saja, tetapi ada tangan Allah di dalamnya.

b. Senantiasa bersyukur

Bersyukur atas segala sesuatu baik itu mendapat rezeki atau terlepas dari bahaya merupakan suatu perintah yang harus dilakukan manusia. Salah satu bentuk rasa syukur kepada Allah yaitu dengan melaksanakan kewajiban untuk sholat. Selain itu, menurut perspektif psikologi, perasaan bersyukur akan menghilangkan rasa resah dan memberikan kepuasan tersendiri. Dalam kaitannya tanggung jawab kepada diri sendiri, maka dapat diuraikan sebagai berikut (Kholis, 2008):

1) Bekerja sebagai kewajiban. Islam merupakan agama yang mewajibkan umatnya untuk bekerja. Bekerja bukan semata-mata untuk mendapatkan uang untuk memenuhi kebutuhan saja, lebih dari itu, bekerja merupakan salah satu bukti bahwa manusia merupakan khalifatullah yang patuh atas perintah Allah.

2) Bekerja harus halal dan baik. Disebutkan dalam suatu hadist bahwa hukum bekerja mencari rezeki yang halal adalah wajib. Hal ini bertujuan agar manusia baik jasmani maupun rohani dapat hidup dengan sehat. Salah satunya yaitu memakan makanan yang halal dan thayyib.

3) Menempuh jalan yang lurus. Setiap manusia pada umumnya memiliki tujuan hidup yang baik seperti menjadi manusia yang hidup berkecukupan dan bermanfaat bagi orang lain. Dalam mencapai kesuksesan, manusia hendaknya selalu berpegangan di jalan Allah. Hal ini telah dijelaskan dalam Al-Qur'an bahwa ada tiga dasar untuk mendapatkan jalan yang lurus tersebut yaitu, mengerjakan sholat, mempercayai rukun iman, dan mengeluarkan harta untuk kebajikan.

4) Sabar. Dalam kehidupan di dunia tentu manusia mengalami berbagai kejadian senang maupun sedih. Sabar merupakan kunci ketika seseorang nengalami peristiwa sedih dalam hidupnya. Dalam Al-Qur'an sabar merupakan salah satu sifat yang sangat terpuji.

5) Sederhana, tidak boros dan tidak mubazir. Allah senantiasa mengajarkan 
umatnya untuk sederhana ketika berpakaian, makan atau minum, bersederhana suara ketika berdo'a dan sederhana ketika belanja. Karena salah satu sifat buruk yang dimiliki manusia yang tertuang dalam Al-Qur'an adalah suka melampaui batas.

6) Jujur. Allah telah menegaskan dalam Al-Qur'an bahwa jujur merupakan sikap yang harus diterapkan dalam seluruh aspek kehidupan. Bahkan dalam Al-Qur'an disebutkan bahwa orang yang mendzalimi dan menganiaya diri sendiri merupakan orang-orang yyang tidak jujur.

7) Berkeyakinan dan optimis. Ragu merupakan salah satu dari berbagai macam sifat yang dimiliki oleh orang munafik. Sehingga seseorang harus memiliki keyakinan yang kuat agar hilang rasa ragu dalam diri.

8) Berupaya terus meningkatkan kualitas. Seiring berkembangnya zaman, kemampuan manusia akan suatu hal juga terus berkembang, salah satunya yaitu teknologi. Oleh sebab itu, sebagai manusia penting untuk selalu meng-upgrade kemampuan agar skill yang dimiliki terus berkembang dan mampu menjadi manusia yang berkualitas.

9) Berilmu. Agama Islam merupakan agama yang menjunjung tinggi ilmu. Bahkan dalam Al-Qur'an Allah berfirman "Allah akan meninggikan orang-orang yang beriman diantaramu dan orang-orang yang diberi ilmu pengetahuan beberapa derajat." Selain itu, orang yang berilmu memiliki kecenderungan lebih bijaksana daam bersikap dan mengambil keputusan.

10) Bersifat waspada. Guna menghindari kerugian atau hal-hal negatif lainnya, maka penting sekali memiliki sikap waspada. Bahkan Allah swt memerintahkan umatnya untuk tidak lalai, khususnya dalam beribadah kepada Allah.

11) Tidak menunda pekerjaan dan menjaga kehormatan. Waktu adalah hal yang amat penting, sehingga sebagai manusia haruslah pandai-pandai me-manage waktu yang dimiliki. Menunda pekerjaan artinya membiarkan waktu hilang secara sia-sia. Padahal waktu tersebut dapat menjadi waktu yang produktif.

12) Bersih. Bersih memiliki arti yang luas. Manusia hendaknya menjaga kebersihan rohani dan jasmaninya, artinya jiwa dan pikiran manusia harus sama-sama terjaga kesuciannya agar terhindar dari pikiran negatif yang merugikan.

c. Berzakat dan berinfaq

Mengeluarkan sebagian harta yang dimiliki untuk kemaslahatan umat merupakan suatu hal yang positif. Menyisihkan harta untuk orang yang 
membutuhkan seperti zakat atau infaq dapat digunakan sebagai penyuci harta yang dimiliki selama ini. Selain karena perintah Allah, zakat atau infaq juga memberikan banyak manfaat bagi orang lain maupun bagi diri sendiri.

d. Berkata benar

Salah satu tanda orang munafik adalah selalu berkata dusta, namun sebaliknya berkata benar merupakan ciri orang beriman. Selain itu, Allah juga senantiasa mengasihi orang-orang yang benar dalam berkata dan bersaksi serta adil dalam memberikan suatu keterangan.

e. Memiliki sifat amanah, adil, pemaaf, tidak bakhil dan menjauhi sifat hasad.

\section{Ciri Etos kerja Islami}

a. Baik dan Bermanfaat. Islam hanya memerintahkan atau menganjurkan pekerjaan yang baik dan bermanfaat bagi manusia, agar setiap pekerjaan mampu memberi nilai tambah dan mengangkat derajat manusia baik secara individu atau kelompok.

b. Kemantapan atau Perfectness. Kualitas kerja yang mantap atau perfect merupakan sifat pekerjaan tuhan kemudian menjadi kualitas pekerjaan yang Islami yang berarti pekerjaan mencapai standar ideal secara teknis. Diperlukan dukungan pengetahuan dan skill yang optimal. Dalam konteks ini Islam mewajibkan umatnya agar terus menambah atau mengembangkan ilmunya dan tetap berlatih.

c. Kerja Keras, Tekun dan Kreatif. Kerja keras dalam islam disebut Mujahadah yakni mengerahklan segenap daya dan kemampuan yang ada dalam merealisasikan setiap pekerjaan yang baik sesungguhnya Allah SWT telah menyediakan fasilitas segala semberdaya yang diperlukan, tinggal peran manusia sendiri dalam memobilisasi serta mendayagunakan secara optimal, dalam rangka melaksanakan apa yang di ridhoi Allah.

d. Berkompetisi dan Tolong Menolong. Al-Qur'an dalam beberapa ayatnya menyerukan persaingan dalam kualitas amal shalih (fastabiqul khoirot). Oleh karena dasar semangat dalam kompetisi Islami adalah ketaatan kepada Allah dan ibadah serta amal sholeh maka wajah persaingan itu tidaklah seram, akan tetapi untuk ta'awun.

e. Objektif. Objektif dalam Islam diistilahkan dengan sidiq artinya mempunyai kejujuran dan selalu melandasi ucapan, keyakinan dan amal perbuatan dengan nilai-nilai yang benar dalam Islam. Tidak ada kontradiksi antara realita dilapangan dengan konsep kerja yang ada. 
f. Disiplin atau Konsekuen. Sikap ini merupakan sikap moral atau dalam Islam disebut amanah. Allah memerintahkan untuk menepati janji adalah bagian dari dasar pentingnya sikap amanah janji atau uqud dalam ayat tersebut mencakup seluruh hubungan baik dengan tuhan, diri sendiri, orang lain dan alam semesta. Untuk menepati amanah tersebut dituntut kedisiplinan yang sungguh-sungguh terutama yang berhubungan dengan waktu serta kualitas suatu pekerjaan yang semestinya dipenuhi.

g. Konsisten dan Istiqomah. Istiqomah dalam kebaikan ditampilkan dalam keteguhan dan kesabaran sehingga menghasilkan sesuatu yang maksimal. Istiqomah akan menumbuh kembangkan suatu sistem yang baik, jujur dan terbuka.

h. Percaya diri dan Kemandirian. Sesungguhnya daya inovasu dan kreatifitas hanyalah terdapat pada jiwa yang merdeka, karena jiwa yang terjajah akan terpuruk dalam penjara nafsunya sendiri, sehingga dia tidak pernah mampu mengaktualisasikan aset dan kemampuan serta potensi ilahiyah yang ia miliki yang sungguh besar nilainya.

i. Efisien dan Hemat. Agama Islam sangat menghargai harta dan kekayaan. Kemaslahatan harta tergantung perilaku hemat dan efisien dalam pemanfaatannya, agar hasil yang dicapai juga maksimal. Namun sifat hemat disini tidak sampai kepada kerendahan sifat yaitu kikir atau bakhil.

\section{Posisi Kerja}

a. Kerja dan Eksistensi Manusia

Bekerja adalah sesuai dengan kodratnya sekaligus menjadi cara untuk memperoleh kebahagiaan di dunia dan akhirat. Selain itu, kerja merupakan sumber rezeki. Maka Islam menganjurkan untuk rajin bekerja agar dapat menikmati kehidupan duniawi dan dapat menginfakkan sebagian harta yang dihasilkan. Amat jelas, amal dan kerja memiliki makna eksistensi dalam hidup dan kehidupan seorang muslim. Karena berhasil atau tidak dan tinggi rendahnya kualitas hidup mereka masing-masing ditentukan oleh amal dan kerjanya. Jadi, eksistensi muslim dan muslimah terletak pada amal dan kerja mereka masing-masing.

Banyak ayat-ayat al-Qur'an yang mengisyaratkan kerja berkaitan dengan eksistensi manusia, antara lain Q.S al-Kahfi/18:7

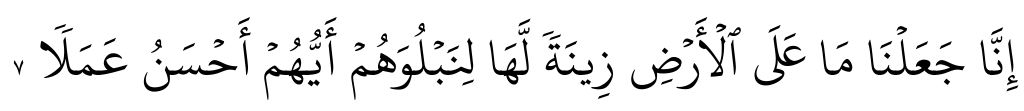


Artinya: "Sesungguhnya Kami telah menjadikan apa yang di bumi sebagai perhiasan baginya, agar Kami menguji mereka siapakah di antara mereka yang terbaik perbuatannya".

Pada ayat lain Allah juga berfirman,

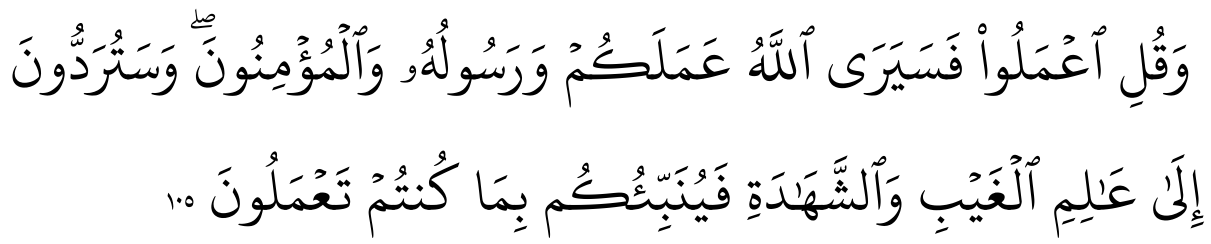

Artinya: Dan Katakanlah: "Bekerjalah kamu, maka Allah dan Rasul-Nya serta orang-orang mukmin akan melihat pekerjaanmu itu, dan kamu akan dikembalikan kepada (Allah) Yang Mengetahui akan yang ghaib dan yang nyata, lalu diberitakan-Nya kepada kamu apa yang telah kamu kerjakan”. (Q.S. AT-Taubah (9): 105)

b. Dari Iman Sampai Kerja

Perlu diperhatikan bahwa Allah bila menyebut perkataan alladziina aатапии dalam ayat al-Qur'an selalu menyambungnya dengan wa'amilushaalihaati. Hal tersebut menandakan bahwa iman harus disertai amal saleh atau pekerjaan yang baik. Amal saleh dalam kehidupan adalah bentuk nyata dari iman. Islam tidak memerintahkan suatu hal kecuali bila terdapat alasan, dengan adanya kemampuan dan faktor pendukung agar terlaksananya perintah itu. Maka, agar berhasil dalam pelaksanaannya nanti, seorang individu perlu membekali diri dengan kemampuan dan sarana-sarana pendukung.

Bekerja demi terlaksananya " $m a$ 'isyah" atau penghidupan yang lebih baik merupakan kewajiban. Sesuai dengan isi kandungan perintah Allah dalam Q.S al-Anfal/8:27 agar orang beriman tidak melalaikan amanah (termasuk anak dan keluarga), maka bekerja mencari rizki untuk memenuhi kehidupan termasuk usaha memenuhi amanah seorang muslim. Sedangkan menginfakkan sebagian harta yang diperoleh juga jelas merupakan penjabaran tanggung jawab sosial. Keharusan kerja bagi manusia mencapai tingkat "tugas istimewa" hingga keengganan atau ketidakmauan untuk bekerja bukan sekedar merugikan individu yang bersangkutan saja, keluarga bahkan masyarakat luas pun ikut terkena dampak negatifnya. Berusaha memperoleh rizki melalui kerja produktif adalah hak Allah disamping hak manusia

\section{Etika Kerja}

Dalam memilih seseorang ketika akan diserahkan tugas Rasulullah SAW melakukannya dengan selektif. Diantaranya dilihat dari segi keahlian, keutamaan iman dan kedalaman ilmunya. Sebagaimana Rasulullah SAW bersabda 
"sesungguhnya Allah mencintai salah seorang di antara kamu yang melakukan pekerjaan dengan itsqon (tekun, rapi dan teliti) (H.R Baihaki). Dalam Al-Qur'an hal yang penting diperhatikan tetang etika kerja adalah: pertama, adanya keterkaitan individu terhadap Allah kesadaran dalam allah melihat (ihsan), mengontrol dalam keadaan apapun dan akan menghisab semua amal perbuatan secara adil kelak akhirat. Kesadaran inilah yang menuntut individu untuk bersikap cermat dan bersungguh-sungguh dalam bekerja dan berusaha mendapat ridho Allah. Kedua, berusaha dengan cara yang halal dalam semua jenis pekerjaan.

a. Tanggungjawab Sosial

Bagaimanakah cara orng kota berderma dan mengungkapkan ras kepedulianya terhadap sesama? Cara orang kota mengekspresikan kedermawananya bukan hanya dengan di ukur secara financial saja, melainkan juga dediksi mereka dalam menyediakan waktu untuk mengabdi diri pada institusi, menyumbangkan pemikiran untuk kebaikan bersama, dan menyisihkan tenaganya untuk menkadi relawan dalam sebuah komunitas.

Relawan adalah pihak-pihak yang memvberikan sumbangan tenaga, pikiran pengetahuan, dan keahlianya kepada pihak yang lain yang membutuhkan untuk mencapai sebuah tujuan. Pada dasarnya firah individu adalah kebaikan, maka menjadi relawan merupakan salah satu cara untuk menyalurkan kecenderungan individu kepada kebaikan melalaui aksinyata memeberikan manfaat pada pihak lain.

Bagi seorang relawan pamrih yang bersifat finansial bukanlah faktor diterminan dalam aktivitas mereka. Sebaliknya, kerja-kerja relawan menempatkan pelayanan lebih utama ketimbang Reward terhadap individu itu sendiri. (latief, 2017)

b. Religiusitas

Religiusitas merupakan bentuk aspek religi yang telah di hayati oleh individu di dalam hati. Makna religiusitas digambarkan dalam beberapa aspek-aspek yang harus dipenuhi sebagai petunjuk mengenai bagaimana cara menjalankan hidup dengan benar agar manusia dapat mencapai kebahagiaan di dunia dan akhirat. Islam adalah suatu cara hidup yang Dapat membimbing seluruh aspek kehidupan manusia dengan akidah, syariah, dan akhlaq (Karim, 2011). Hubungan antara religiuitas dengan peningkatan moral masih menajadi bahan perdebatan ahli agama. Ada yang melihat hubungan religiuitas dan peningkatan moral merupakan hubungan yang saling terikat namun, di sisi lain ada pula yang menganggap keduanya saling terpisah. Maksudnya yaitu bahwa 
konsep religiuitas dan etika merupakan hal yang terpisah dan tidak ada kaitannya (Burks dan Sellani, dalam Putri 2015).

Ada dua kategori religiuitas menurut Burks dan Sellani, yaitu religious commitment dan religious affiliation. Religious commitment yaitu mengukur tingkat religiuitas seorang individu berdasarkan komitmen indivdu tersebut terhadap gaya hidup atau kepercayaan religi pada organisasi religius, contohnya dapat diukur dari seberapa sering individu tersebut datang ke temapt ibadah, memberikan sumbangan kebaikan atau keterlibatan individu tersebut pada acara keagamaan. Sedangkan religious affiliation lebih mangacu pada keanggotaan seorang individu pada suatu lembaga tertentu. Religious affiliation dapat berupa universitas, tempat ibadah, atau lembaga lainnya. (Burks dan Sellani, dalam Putri 2015).

c. Filantropi

Istilah filantropi sendiri berasal dari bahasa latin philanthropia atau bahasa yunani philo dan anthropo, yang berarti "cinta manusia". Filantropi adalah kepedulian seseorang atau sekelompok orang kepada orang lain berdasarkan kecintaan pada semua manusia. Filantropi kerap diekspresikan dengan cara menolong orang yang membutuhkan akan tetapi falsafah filantropi tidak senantiasa mempunyai makna yang sama antara satu budaya dan budaya lainnya (Latief, 2017).

Setidaknya terdapat dua varian filantropi yang berkembang yaitu filantropi tradisional dan filantropi keadilan sosial. Kedua varian filantropi tersebut tentu memiliki perbedaan. Pelaksanaan filantropi tradisional cenderung tidak berkelanjutan dan beraksi pada ruang karitas semata. Sedangkan filantropi keadilan sosial lebih menggali makna filantropi sesungguhnya yaitu membantu memecahkan masalah publik dengan program yang memiliki ciri-ciri seperti mengubah sistem, sifatnya berkelanjutan, menyelesaikan masalah ditingkat struktur dan bergerak pada aspek makro (Abidin, 2012)

Konsep filantropi tidak semata-mata hanya bergelut dengan uang atau materi saja. Dapat diartikan pula keterlibatan pada seluruh aspek kehidupan manusia dengan penuh dedikasi, kerelaan, waktu luang, atau sumbangan dalam bentuk materi atau dalam bentuk lain yang masih berkaitan dengan konsep filantropi. Filantropi merupakan modal sosial yang telah membaur dengan tradisi khususnya pada masyarakat yang tinggal di pedesaan. Sebagai contoh yaitu tradisi memberikan sumbangan kepada keluarga, tetangga atau teman yang membutuhkan. Selain itu, filantropi juga merupakan bentuk ajaran agama yang 
baik yang memperhatikan masalah sosial seperti kemiskinan. Ichsan (2018) menjelaskan bahwa dalam harta pribadi tetap tersimpan hak orang lain dalam bentuk zakat, infaq, dan sadaqah berdasarkan pendekatan syariah. Untuk itu, konsep filantropi dapat dikatakan yaitu untuk menjembatani antara muzakki (pemberi zakat) dan mustahik (penerima zakat).

Gerakan filantropi bertujuan untuk menciptakan keadilan sosial masih terus dilakukan banyak kalangan untuk mencari bentuk terbaik dalam menyelasaikan atau mengurangi beban sosial dan ekonomi masyarakat, termasuk melalui gerakan "filantropi kreatif". Seiring dengan persoalan sosial yang semakin rumit gerakan filantropi melakukan pembaruan dan pemodernan. Dalam konteks perubahan sosial pemaknaan filantropi pun semakin dinamis.

Ada prinsip keadilan sosial yang diemban dalam gerakan filantropi modern yaitu agar kaum fakir dan miskin serta kalangan yang tidak beruntung melalui pendampingan yang serius dan konsisten dapat merasakan materi yang disumbangkan oleh kalangan yang punya dan peduli. Namun lebih dari itu, melalui pendampingan yang serius dan konsisten diharapkan bahwa mereka yang tidak beruntung dapat berdikari dikemudian hari.

Seiring diperdebatkan apakah betul kegiatan filantropi modern akan lebih produktif dalam memanfaatkan harta sedekah atau dana sosial dibandingkan dengan konsep tradisional yang telah berjalan dalam masyarakat selama ribuan tahun. Dalam soal ini, ada dua hal yang barangkali dapat kita pertimbangkan (latief, 2017):

Pertama, di negara-negara berkembang, baik konsep pelayanan maupun pendampingan masih sama-sama diperlukan. Satu sama lain memiliki kelebihan dan kekurangan yang sejatinya bisa saling melengkapi. Misalnya, pelayanan dianggap satu bentuk kegiatan yang mencoba memberikan solusi terhadap problem sosial masyarakat dalam jangka pendek. Namun perlu pula diingat bahwa bentuk pelayanan yang saat ini dilakukan oleh beberapa organisasi sosial dan keagamaan masih berperan penting dalam menangani persoalan-persoalan khusus.

Kedua, program-program advokasi dianggap salah satu bentuk aktifitas filantropi yang lebih relevan untuk diterapkan dewasa ini. Program jenis ini tidak hanya diharapkan dapat memberikan satu bentuk perubahan sosial dalam masyarakat secara lebih besar dan sistematis, tetapi juga dapat memperkuat basil masyarakat sipil. Daya jangkau sebuah program advokasi memang tidak luas dan organisasi yang dibentuknya tidak sebanyak kegiatan pelayanan. Lembaga 
advokasi juga lebih fokus dalam mebidik target, lebih dalam menyusun program perencanaan dan implementasinya, serta lebih jelas dalam mendevinisikan dampak dan capaian indikator kinerja programnya. Potensi dana yang memiliki bisa cukup besar dan jaringannya pun lebih luas. Namun, organisasi dengan corak seperti ini jumlahnya tidak banyak, dan sustaininilitasnya terhadap program terkadang sangat bergantung kepada organisasi donor tertentu. Penyiapan program penilaian terhadap subjek yang akan dikaji atau diberdayakan sangat mungkin juga memrlukan waktu yang lama.

Ketiga, sebagai kelanjutannya, yang diperlukan kemudian adalah mengembangkan lembaga yang berorientasi pelayanan dan berorientasi advokasi secara lebih optimal, saling melengkapi dan saling mengisi kekurangan satu sama lainnya. Hal ini senada dengan argumen Helmut K. Anheier dan Diana Leat bahwa filantropi ilmiah dan neo-filantropi ilmiah terkadang miskin dengan konsep pelayanan terlalu fokus pada proses dan kurang memberi perhatian pada peran. Upaya untuk mengoptimalisasikan filantropi antara lain dengan cara mengoptmalisasikan keunikan peran-peran yang telah dimainkan oleh masyarakat melalui berbagai jenis lembaga atau organisasi kerelawanan yang telah mereka bentuk.

6. Hipotesis Penelitian

Dari pemaparan teori dan logika penelitian terdahulu diatas, maka dapat ditarik hipotesis penelitian sebagai berikut:

Hipotesis 1: Religiusitas berpengaruh positif terhadap etos kerja islami

Hipotesis 2: Tanggungjawab sosial berpengaruh positif terhadap etos kerja islami

\section{METODE}

Jenis penelitian yang digunakan pada penelitian ini yaitu jenis penelitian kuantitatif deskriptif. Penelitian ini dilaksanakan di tiga lembaga filantropi yaitu lembaga Amil Zakat Muhammadiyah (LazisMu). Pengumpulan data yang dilakukan yaitu level individu dengan pengambilan data one shoot/cross sectional.

a. Sampel dan Prosedur

Peneliti membagikan 50 kuisioner kepada karyawan Lembaga Amil Zakat Muhammadiyah. Seluruh kuesioner dapat diolah yaitu berjumlah 50 kuesioner. Dalam penelitian ini karyawan yang berjenis kelamin pria sebanyak $84 \%$. Distribusi usia responden terbanyak berkisar antara 20 hingga 26 tahun sebanyak $48 \%$ dan yang paling sedikit yaitu diatas 40 tahun. Untuk tingkat pendidikan didominasi oleh Diploma/S1 yaitu sebanyak $72 \%$. Untuk status kerja mayoritas didominasi oleh 
pekerja tetap yaitu sebanyak $72 \%$ dan sisanya karyawan kontrakl $28 \%$.

b. Pengukuran

Seluruh pengukuran variabel dalam penelitian ini menggunakan skala Likert 5 point yaitu 1 mewakili jawaban sangat tidak setuju dan 5 mewakuli jawaban sangat setuju (Sugiono,2012). Karyawan Lembaga amil Zakat Muhammadiyah diminta untuk menjawab pernyataan-pernyataan yang meliputi pengaruh religiusitas dan tanggungjawab sosial terhadap etos kerja islami. Peneliti menggunakan kuesioner yang telah digunakan oleh penelitian terdahulu.

Uji validitas menggunakan pearson correlation yaitu mengkorelasikan antara itim dengan total item kuesioner tersebut. Untuk pengujian reliabilitas peneliti menggunakan crombach alpha. Alat analisis yang digunakan yaitu regresi linier berganda.

\section{HASIL}

a. Pengujian Instrumen

Pengujian validitas dalam penelitian ini mengkorelasikan item dengan total item. Dapat dilihat dalam tabel 1, seluruh item pernyataan dalam penelitian ini valid karena tingkat signifikansi korelasinya kurang dari 5\%. Sedangkan untuk pengujian reliabilitas seluruh variabel dikatakan reliabel karena nilai crombach alpha lebih besar dari 0.60, dapat dilihat dalam tebel 2 .

Tabel 1. Uji Validitas Kuisioner

\begin{tabular}{ccccc}
\hline Variabel & Butir & $\begin{array}{c}\text { Koefisien } \\
\text { korelasi }\left(r_{x y}\right)\end{array}$ & Signifikansi & Keterangan \\
\hline Religiusitas $\left(\mathrm{X}_{1}\right)$ & $\mathrm{X}_{1.1}$ & 0.661 & 0.000 & Valid \\
& $\mathrm{X}_{1.2}$ & 0.672 & 0.000 & Valid \\
& $\mathrm{X}_{1.3}$ & 0.801 & 0.000 & Valid \\
& $\mathrm{X}_{1.4}$ & 0.797 & 0.000 & Valid \\
& $\mathrm{X}_{1.5}$ & 0.617 & 0.000 & Valid \\
& $\mathrm{X}_{1.6}$ & 0.531 & 0.000 & Valid \\
& $\mathrm{X}_{1.7}$ & 0.654 & 0.000 & Valid \\
Tanggungjawab & $\mathrm{X}_{2.1}$ & 0.629 & 0.000 & Valid \\
sosial (X $)$ & $\mathrm{X}_{2.2}$ & 0.775 & 0.000 & Valid \\
& $\mathrm{X}_{2.3}$ & 0.760 & 0.000 & Valid \\
& $\mathrm{X}_{2.4}$ & 0.810 & 0.000 & Valid \\
& $\mathrm{X}_{2.5}$ & 0.801 & 0.000 & Valid \\
& $\mathrm{X}_{2.6}$ & 0.654 & 0.000 & Valid \\
& $\mathrm{X}_{2.7}$ & 0.745 & 0.000 & Valid \\
Etos Kerja Islami & $\mathrm{Y}_{1}$ & 0.746 & 0.000 & Valid \\
& & & &
\end{tabular}




\begin{tabular}{lllll}
\hline (Y) & $\mathrm{Y}_{2}$ & 0.811 & 0.000 & Valid \\
& $\mathrm{Y}_{3}$ & 0.782 & 0.000 & Valid \\
& $\mathrm{Y}_{4}$ & 0.825 & 0.000 & Valid \\
\hline
\end{tabular}

Tabel 2. Ikhtisar Uji Reliabilitas Kuisioner

\begin{tabular}{clccl}
\hline No. & \multicolumn{1}{c}{ Variabel } & $\begin{array}{c}\text { Koefisien } \\
\text { Alpha } \\
\text { Cronbach }\end{array}$ & Kriteria & Keterangan \\
& & 0,858 & $>0,60$ & Reliabel \\
\hline 1. & Religiusitas $\left(\mathrm{X}_{1}\right)$ & 0,802 & $>0,60$ & Reliabel \\
2. & Tanggungjawab sosial & & & \\
& $\left(\mathrm{X}_{2}\right)$ & 0,800 & $>0,60$ & Reliabel \\
\hline
\end{tabular}

b. Pengujian Hipotesis

Metode analisis data yang digunakan dalam penelitian ini adalah Regresi Linier Berganda untuk menguji hipotesis 1 dan 2. Hasil pengujian hipotesis ini dapat dilihat dalam tabel 3 berikut ini.

Tabel 3. Pengujian Hipotesis

\begin{tabular}{|c|c|c|c|c|c|}
\hline \multirow[t]{2}{*}{ Model } & \multicolumn{2}{|c|}{$\begin{array}{l}\text { Unstandardized } \\
\text { Coefficients }\end{array}$} & \multirow{2}{*}{$\begin{array}{c}\text { Standardiz } \\
\text { ed } \\
\text { Coefficient } \\
\text { s }\end{array}$} & \multirow[t]{2}{*}{$\mathrm{t}$} & \multirow[t]{2}{*}{ Sig. } \\
\hline & B & $\begin{array}{l}\text { Std. } \\
\text { Error }\end{array}$ & & & \\
\hline (Constant) & 3.907 & 1.999 & & 1.954 & .057 \\
\hline Religiusitas & .099 & .087 & .151 & 1.135 & .262 \\
\hline $\begin{array}{l}\text { Tanggungja } \\
\text { wab Sosial }\end{array}$ & .355 & .074 & .638 & 4.808 & .000 \\
\hline
\end{tabular}

Hipotesis pertama mengatakan bahwa religiusitas berpengaruh positif terhadap etos kerja islami ditolak. Berdasarkan pada Tabel 3, dapat dilihat bahwa religiusitas tidak berpengaruh terhadap etos kerja islami ( $\beta=-0,09 ; \mathrm{t}=1,135 ; \mathrm{p}>0,05)$. Karyawan yang bekerja dalam Lembaga Amil Zakat sudah sepatutnya memiliki religiusitas dalam dirinya sehingga karakter religiusitas tidak lagi hal penentu dalam bekerja. Hasil ini tidak sejalan dengan dugaan peneliti bahwa religiusitas berpengaruh positif terhadap etos kerja islami. Hipotesis kedua mengatakan bahwa tanggungjawab sosial berpengaruh positif terhadap etos kerja islami karyawan didukung. Berdasarkan pada Tabel, dapat dilihat bahwa tanggungjawab sosial berpengaruh positif terhadap etos kerja islami $(\beta=0,335 ; t=4,808 ; p<0,01)$. Hal ini dikarenakan Lembaga Amil Zakat yang merupakan Lembaga sosial harus memiliki 
karyawan yang mempunyai karakter bertanggungjawab secara sosial yang tinggi karena melayani umat. Sejalan dengan dugaan peneliti bahwa tanggungjawab sosial berpengaruh positif terhadap etos kerja islami karyawan Lembaga Amil Zakat.

Besarnya hasil penghitungan nilai koefisien regresi menunjukkan R2 sebesar 0,561 atau $56,1 \%$. Hal ini dapat diartikan bahwa 56,1\% variasi perubahan pada variabel etos kerja islami, ditentukan oleh religiusitas dan tanggungjawab sosial sedangkan $43,9 \%$ sisanya disebabkan oleh variabel lain yang tidak termasuk dalam model penelitian ini.

Tabel 4. Analisis Koefisien Diterminasi $\left(\mathrm{R}^{2}\right)$

\begin{tabular}{lcccr}
\hline Model & $\mathrm{R}$ & $\begin{array}{c}\mathrm{R} \\
\text { Square }\end{array}$ & $\begin{array}{c}\text { Adjusted R } \\
\text { Square }\end{array}$ & $\begin{array}{c}\text { Std. Error } \\
\text { of the } \\
\text { Estimate }\end{array}$ \\
\hline 1 & $.749^{\mathrm{a}}$ & .561 & .543 & 1.153 \\
\hline
\end{tabular}

\section{PEMBAHASAN}

Tujuan dari penelitian ini adalah untuk menguji pengaruh positif religiusitas dan tanggungjawab sosial terhadap etos kerja islami. Tanggungjawab sosial dapat berpengaruh positif terhadap etos kerja islami, namun tidak demikian dengan religiusitas karyawan yang tidak berpemngaruh terhadap etos kerja islami di Lembaga Amil Zakat Muhammadiyah.

Hipotesis pertama mengatakan bahwa religiusitas berpengaruh positif terhadap etos kerja islami ditolak. Hal ini dikarenakan sifat religiusitas merupakan salah satu syarat yang dimiliki oleh karyawan Lembaga Amil Zakat yang basisnya sosial kemanusiaan, sehingga religiusitas bukan lagi faktor utama dalam menentukan tingginya etos kerja islami. Selain itu religiusitas merupakan hubungan ukhrowi antara manusia dengan penciptanya dan etos kerja islami merupakan pekerjaan duniawi, sehingga tidak ada korelasi secara langsung antara religiusitas dengan etos kerja islami. Alasan lain tidak didukungnya hipotesis pertama ini yaitu dalam mencapai tingginya etos kerja islami, karyawan membutuhkan skill yang mumpuni dalam bidang di pekerjaannya seperti manajemen pekerjaan yang tidak terdapat dalam religiusitas, sehingga religiusitas tidak berpengaruh terhadap etos kerja islami.

Hipotesis kedua yang mengatakan bahwa tanggungjawab sosial berpengaruh positif terhadap etos kerja islami didukung. Lembaga Amil Zakat Muhammadiyah yang bergerak dalam bidang sosial kemanusiaan sangat ditentukan dari karakter individu yang memiliki tanggungjawab sosial yang tinggi, yang berujung pada meningkatnya 
etos kerja islami dari para karyawannya. Karyawan yang memiliki tanggungjawab yang baik maka akan lebih bertanggungjawab terhadap pekerjaannya yang merupakan bagian dari etos kerja islami. Dari alasan-alasan yang dikemukakkan peneliti diatas, maka dukungan hipotesis kedua dapat dijelaskan.

a. Implikasi Penelitian

Implikasi teoritis. Dari hasil penelitian ini yaitu dapat menjadi bukti empiris yang menjelaskan pentingnya peran tanggungjawab sosial dalam meningkatkan etos kerja islami dalam sebuah Lembaga Amil Zakat khususnya LazisMu. Penelitian ini membuktikan bahwa tanggungjawab sosial dapat menjadi alternatif penelitian selanjutnya untuk dijadikan variabel prediktor dalam melihat etos kerja islami.

Implikasi praktis. Hasil dari penelitian ini memberikan kontribusi yang sangat penting bagi para pengambil kebijakan dalam perusahaan, khususnya dalam Lembaga Amil Zakat. Dari hasil penelitian ini yaitu peran tanggungjawab sosial dalam meningkatkan etos kerja islami di Lembaga Amil Zakat khususnya LazisMu sangat penting. Para manajer yang akan melakukan perekrutan karyawan Lembaga Amil Zakat diharapkan memperhatikan karakteristik karyawan seperti memiliki tanggungjawab sosial yang tinggi.

b. Keterbatasan Penelitian dan Saran Penelitian Mendatang

Penelitian ini memiliki beberapa keterbatasan/kelemahan yang harus diperbaiki dalam penelitian mendatang. Pertama, penyebaran kuesioner ada yang melalui online sehingga keabsahan data respondent tidak sepenuhnya valid. Penelitian selanjutnya diharapkan dapat menyebar kuesioner langsung kepada respondent secara keseluruhan. Kedua, penelitian ini sangat mungkin terdapat common method bias. Penggunaan metode penilaian oleh diri sendiri (self reported) untuk mengukur persepsi karyawan. Namun, peneliti telah berupaya semaksimal mungkin untuk mengurangi kecenderungan terjadinya bias tersebut dengan menjamin kerahasiaan data diri responden serta menjelaskan dan meyakinkan responden terhadap tujuan penelitian ini dilakukan. Penelitian selanjutnya, disarankan agar dapat mengukur persepsi individu tidak hanya menggunakan metode penilaian self reported, namun juga dengan menggunakan metode penilaian dari atasan, sehingga didapat penilaian yang lebih valid.

\section{SIMPULAN}

Pengaruh religiusitas dan tanggungjawab sosial terhadap etos kerja islami karyawan Lembaga Amil Zakat Muhammadiyah (LAZISMU) sebagai salah satu lembaga filantropi menunjukkan bahwa tanggungjawab sosial dapat meningkatkan etos 
kerja islami karyawan di Lembaga Amil Zakat Muhammadiyah dengan koefisien regresi sebesar $(\beta=0.355$; $p$-value $=0.000)$, untuk karakteristik religiusitas tidak berpengaruh terhadap etos kerja islami karyawan di Lembaga Amil Zakat nasional tersebut $(\beta=0.099$; $p$-value= 0.262). Hal ini membuktikan bahwasannya Lembaga Amil Zakat yang merupakan lembaga sosial, memerlukan karyawan yang memiliki tanggungjawab sosial yang tinggi.

\section{DAFTAR PUSTAKA}

Abidin, Zainal. (2012). Manifestasi dan Latensi Lembaga Filantropi Islam dalam Praktik Pemberdayaan Masyarakat: Suatu Studi di Rumah Zakat Kota Malang. Salam, Jurnal Studi Masyarakat Islam. Vol. 15. No. 2. 197-214.

Asifudin, Ahmad janan. (2004). Etos Kerja Islami. Muhammadiyah University Press, Universitas Muhammadiyah Surakarta.

Baidhawy, Z. (2017). Muhammadiyah dan Spirit Islam Berkemajuan dalam Sinaran Etos Alqur'an. Jurnal AFKARUNA. Vol. 13. No. 1. 17 - 47.

Dragon, Muham Sakura. (2015). Etos Kerja Dalam Pandangan Agama Islam. Sakura Dragon SPC.

Hapsari, T.B. (2018). The History of Contemporary Indonesian Muslim Groups and Muslim Media. Jurnal AFKARUNA. Vol. 14. No. 1. 101 - 127.

Ichsan, N. (2018). Tinjauan Penerapan Pungutan Pajak dan Zakat Menurut Konsep Ekonomi Islam di Indonesia. Islamadina (Jurnal Pemikiran Islam). Vol. 19. No. 2. 75-91.

Karim, Adiwarman. (2011). Bank Islam: Anlisis Fikih dan Keuangan. Jakarta: Rajawali Press

Kholis, Nur. (2008). Etos Kerja Islami. Mukaddimah, Jurnal Studi Islam. No. 22 . Th. XIII. Hal. 22-42.

Latief, Hilman. (2017). Melayani Umat: Filantropi Islam dan Ideologi Kesejahteraan Kaum Modernis. Jakarta: PT. Gramedia Pustaka Utama.

Mubarok, A., \& Fanani, B. (2014). Penghimpunan Dana Zakat Nasional (Potensi, Realisasi dan Peran Penting Organisasi Pengelola Zakat). PERMANA. Vol. 5 No. 2. $7-16$.

Muslih, M. (2018). Rekonstruksi Nalar Keagamaan; Ikhtiar Menemukan Konteks Agama Bagi Pengembangan Sains. Jurnal AFKARUNA. Vol. 14. No. 2. 190 218.

Putri, Caesar M. (2016). Pengaruh Jalur Pelaporan dan Tingkat Religiusitas terhadap Niat Seseorang Melakukan Wistleblowing. Jurnal Akuntansi dan Investasi. Vol. 17. No. 1. 42-52.

Putri, S.A.M \& Firmansyah, E.J.R. (2017). Optimalisasi Laku Pandai berbasis Masjid 
guna Literasi dan Inklusi Keuangan Syariah Berkelanjutan. Jurnal Ekonomi dan Bisnis Islam. Vol. 3. No. 2. $106-121$.

Sugiyono. (2012). Metode Penelitian Kuantitatif Kualitatif dan $R \& D$. Bandung: Alfabeta.

Suwarsi, A.A., \& Wulandari, N. P. (2017). Identifikasi Potensi Nasabah Baru Bank Syariah Ditinjau dari Customer Switching Intention. Jurnal Ekonomi dan Bisnis Islam. Vol. 3. No. 2. $168-190$.

Tasmara, Toto. (2004). Membudayakan Etos Kerja Islami. Gema Insani. 